Anna V. Talovskaya', Egor G. Yazikov', Nina A. Osipova', Elena E. Lyapina², Victoria V. Litay ${ }^{3}$, George Metreveli ${ }^{4}$, Junbeum Kim ${ }^{5}$

${ }^{1}$ School of Earth Sciences and Engineering, National Research Tomsk Polytechnic University, 30 Lenin Ave., 634050, Tomsk, Russia

${ }^{2}$ Laboratory of Physics of Climatic Systems, Institute of Monitoring of Climatic and Ecological Systems of the Siberian Branch of the RAS, 10/3 Academichesky Ave., 634055, Tomsk, Russia

${ }^{3}$ Siberian Geotechnical Service, 40 Korolev, 630015, Novosibirsk, Russia

${ }^{4}$ Group of Environmental and Soil Chemistry, Institute for Environmental Sciences, University of Koblenz-Landau, Fortstrasse 7, D-76829 Landau, Germany ${ }^{5}$ CREIDD Research Centre on Environmental Studies \& Sustainability, Department of Humanities, Environment \& Information Technology (HETIC), University of Technology of Troyes, UMR 6281, France

* Corresponding author: talovskaj@yandex.ru

\title{
MERCURY POLLUTION IN SNOW COVER AROUND THERMAL POWER PLANTS IN CITIES (OMSK, KEMEROVO, TOMSK REGIONS, RUSSIA)
}

\begin{abstract}
Although snow cover is studied as an efficient scavenger for atmospheric mercury $(\mathrm{Hg})$, up to now little is known about $\mathrm{Hg}$ behaviour in urban snow cover impacted by thermal power plants (TPPs) during the winter heating season. This study is focused on quantification of $\mathrm{Hg}$ in the particulate phase in snow cover and estimation of atmospheric particulate $\mathrm{Hg}\left(\mathrm{Hg}^{\mathrm{P}}\right)$ depositional fluxes around urban TPPs in cities of Omsk, Kemerovo, Yurga, Tomsk (the south part of Western Siberia, Russia) to provide new insight into $\mathrm{Hg}$ occurrence in urban snow. The results demonstrate that the mean $\mathrm{Hg}$ content in the particulate phase of snow varied from 0.139 to $0.205 \mathrm{mg} \mathrm{kg}^{-1}$, possibly depending on thermal power of TPPs and fuel type used. The estimated mean atmospheric $\mathrm{Hg}^{\mathrm{P}}$ depositional fluxes ranged from 6.6 to $73.1 \mathrm{mg} \mathrm{km}^{-2} \mathrm{~d}^{-1}$. Around thermal power plants atmospheric $\mathrm{Hg}^{\mathrm{P}}$ depositional flux was controlled by particulate load. Higher $\mathrm{Hg}$ contents in the particulate phase of snow and higher atmospheric $\mathrm{Hg}^{\mathrm{P}}$ depositional fluxes observed in relation to the background values, as well as high enrichment factors determined for $\mathrm{Hg}$ in the particulate phase of snow relative to the mean $\mathrm{Hg}$ content in the Earth's crust showed that the snow pollution with $\mathrm{Hg}$ is of anthropogenic origin. The coexistence of $\mathrm{Hg}$ and $\mathrm{S}$ observed for the particulate phase of snow indicated the possible presence of mercury sulfide in this phase. The parameters like Hg content in the particulate phase of snow and $\mathrm{Hg}^{\mathrm{P}}$ atmospheric flux can be used as markers for the identification of coal combustion emission sources.
\end{abstract}


KEYWORDS: snow cover, particulate mercury, coal combustion, deposition, $\mathrm{Hg}^{\mathrm{p}}$ quantification

CITATION: Anna V. Talovskaya, Egor G. Yazikov, Nina A. Osipova, Elena E. Lyapina, Victoria V. Litay, George Metreveli, Junbeum Kim (2019) Mercury Pollution In Snow Cover Around Thermal Power Plants In Cities (Omsk, Kemerovo, Tomsk Regions, Russia). Geography, Environment, Sustainability, Vol.12, No 4, p. 132-147

DOI-10.24057/2071-9388-2019-58

\section{INTRODUCTION}

Snow cover is a natural ground cover in the winter season in several regions (e.g. Siberia, Russian Far East, southern Canada, central and northern Europe) and it is an efficient scavenger of air pollutants caused by fuel combustion, emissions of industries, vehicle exhaust as well as by long-range transport events. Wet and dry deposition of contaminants results in snow cover pollution (Davidson et al. 1996). Therefore, snow cover is the subject of many studies as a reliable indicator of air pollution, and it can provide information on sources of air pollutants (Raputa et al. 2010; Baltrenaite et al. 2014; Yanchenko et al. 2015; Gao et al. 2018).

Mercury $(\mathrm{Hg})$, as one of the greatest toxic trace elements (Tchounwou et al. 2003), can be accumulated in snow cover (Ferrari et al. 2002; Siudek et al. 2014; Douglas et al. 2017), both in inorganic (Ferrari et al. 2002) and organic form (Marusczak et al. 2011) impacting negatively the aquatic and terrestrial ecosystems after snow melting (Wiener et al. 2003). Up to date, many studies have paid attention to Hg content and speciation in polar (Fitzgerald et al. 1991; Douglas et al. 2017) and mountain snow (Ferrari et al. 2002; Huang et al. 2014) to identify $\mathrm{Hg}$ sources and to obtain the information on the past and recent changes in the global cycle of this element. Some researchers (Boutron et al. 1998; Gratz and Keeler 2011) indicated that Hg deposition in snow cover in polar and mountain regions could be due to long-range transport of compounds emitted from coal combustion.

The total mercury concentration in urban snow was evaluated within several studies in Toronto (Brzezinska-Paudyn et al. 1986),
Maine (Nelson et al. 2007), Shanghai (Zhang et al. 2013), Gdynia (Siudek et al. 2014), Svirsk (Grebenshchikova et al. 2017), Ursk (Gustaytis et al. 2018) and Moscow (Galitskaya and Rumyantseva 2012). Some researchers (Nelson et al. 2007; Galitskaya and Rumyantseva 2012; Zhang et al. 2013; Siudek et al. 2014) revealed that during winter season the combustion of coal, which is still applied in numerous countries for the energy generation irrespective of negative impact on the climate, caused high $\mathrm{Hg}$ contents in snow cover within the urban areas. Additionally, Zhang et al. (2013) indicated that biomass combustion, heavy local traffic emissions and secondary aerosols also contributed to $\mathrm{Hg}$ deposition in snow cover. However, much less is known about Hg speciation and behavior in snow cover around urban coal-fired thermal power plants (TPP), being the main emission source of anthropogenic $\mathrm{Hg}$ in the world (UNEP 2013). Coal combustion emissions include three forms of $\mathrm{Hg}$ : (i) gaseous elemental mercury $\left(\mathrm{Hg}^{0}\right)$ representing much frequently ( $\geq 95 \%)$ occurring form of $\mathrm{Hg}$; (ii) bivalent reactive gaseous mercury $\left(\mathrm{Hg}^{2+}\right)$ and (iii) particulate mercury $\left(\mathrm{Hg}^{\mathrm{P}}\right)$ (Galbreath and Zygarlicke 2000). Generally, emissions can be transported locally, regionally, and globally and then deposited at any distance from its sources (Nelson et al. 2010; Raputa et al. 2010; Antonova et al. 2019). Emissions of Hg into the air significantly affect snow cover chemical composition (Siudek et al. 2014; Siudek 2016). It is important to assess snow pollution by Hg with great clarity at regional and local scales. Chemistry of $\mathrm{Hg}$ during wintertime is of crucial interest (Siudek et al. 2014), particularly in cold climatic regions with long wintertime heating season. According to Kim et al. (2012), after emission, gaseous mercury can adsorb onto 
the fine particles in the air. It is expected 으 that the association with particulate phase can facilitate the deposition of $\mathrm{Hg}$, e.g. in snow cover.

Anthropogenic $\mathrm{Hg}$ emission increases during the winter season since TPPs operate more intensively in this period (Siudek et al. 2014). This is especially relevant for urban areas of Western Siberia, where more than $30 \%$ of $\mathrm{Hg}$ emissions originate from coal-fired TPPs (Arbuzov et al. 2015) and $\mathrm{Hg}$ is accumulated in snow cover during a long winter season. Although the large amounts of fine $\mathrm{Hg}^{\mathrm{p}}$ were observed in the ambient air during the winter season in urban and rural areas (Kim et al. 2012) and most of $\mathrm{Hg}$ in snow cover was associated with particulate matter (Huang et al. 2014), there are still some gaps with respect to quantification of $\mathrm{Hg}^{\mathrm{P}}$ in snow cover, particularly near to the emission sources (Nelson et al. 2010) such as TPPs.

Systematic studies on $\mathrm{Hg}^{\mathrm{P}}$ in snow cover within urban areas impacted by TPPs are necessary to understand better the chemistry of emitted and deposited $\mathrm{Hg}$, to obtain knowledge about atmospheric $\mathrm{Hg}^{\mathrm{P}}$ depositional fluxes during winter season, and finally to assess potential human health risk. The importance of further studies on $\mathrm{Hg}^{\mathrm{P}}$ in snow cover is also supported by our earlier research finding showing that around fossil fuel TPP (Tomsk, Western Siberia) Hg was predominantly associated with the particulate phase in snow cover, representing $78 \%$ of total Hg (Talovskaya et al. 2014).

The aim of this study is to provide new insight into the occurrence of $\mathrm{Hg}^{\mathrm{p}}$ deposited in snow cover around urban thermal power plants representing the predominant source for $\mathrm{Hg}$ emissions in such cold climatic region as Western Siberia (Russia). The more specific objectives are (i) quantification of $\mathrm{Hg}$ contents in the particulate phase of snow cover, (ii) estimation of atmospheric $\mathrm{Hg}^{\mathrm{P}}$ depositional fluxes, (iii) identification of Hg-bearing particles in snow cover, and (iv) assessment of TPP contribution to the $\mathrm{Hg}^{\mathrm{P}}$ snow cover pollution.

\section{MATERIALS AND METHODS}

\section{Description of study area}

As shown in Fig. 1, the study area included the following large cities: Omsk, Kemerovo, Tomsk and small city of Yurga, located in the south part of Western Siberia, Russia. These

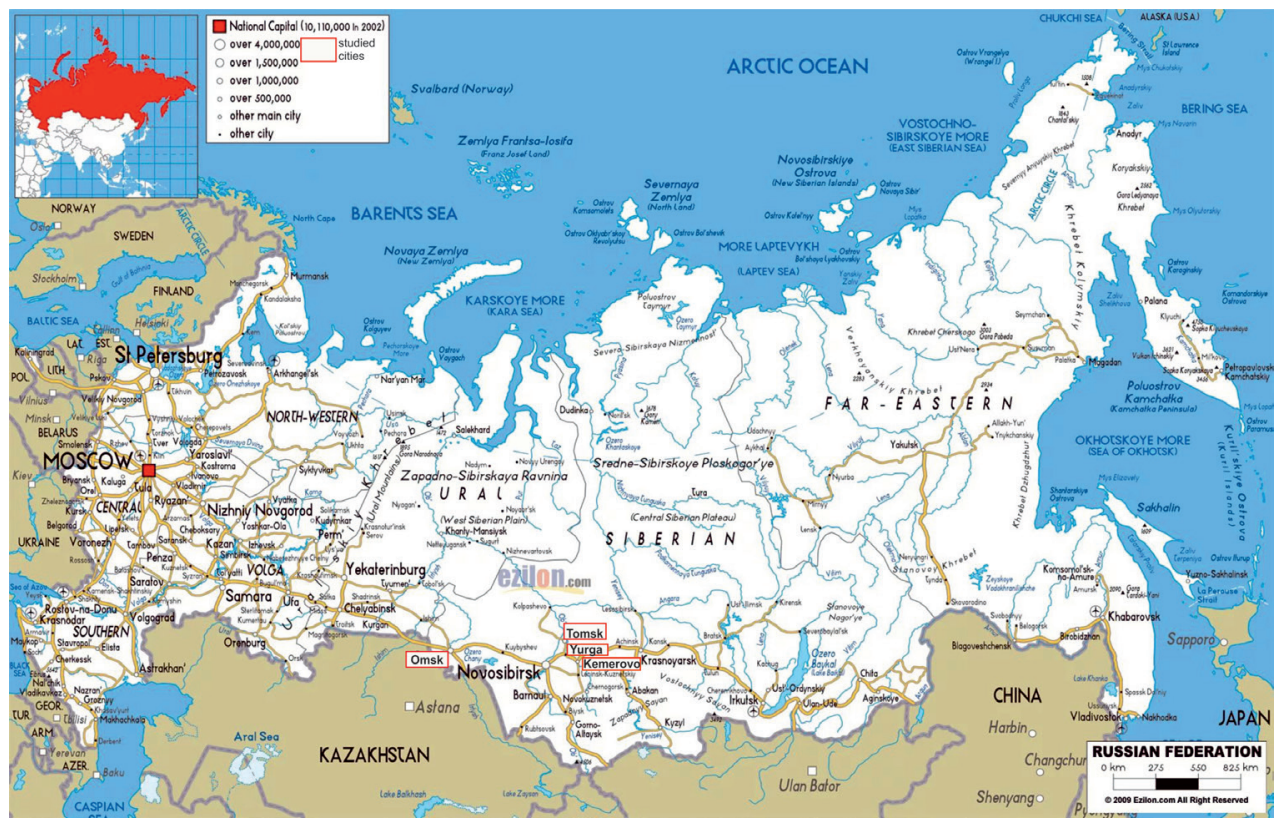

Fig. 1. Location of studied cities (Western Siberia, Russia; source: maps open source, modified) 
cities belong to the industrially-impacted areas where thermal power plants are working during whole year operating more intensively in the wintertime heating season. Moreover, TPP areas are embraced inside a dense urban network, indicating that TPP emissions can diffuse over the urban areas and reach residential districts. The climate varies from a moderate (Omsk) to humid (Kemerovo, Yurga and Tomsk) (open source: Wikipedia). The air temperature ranges from -9 to $-40^{\circ} \mathrm{C}$ in the winter season. The prevailing winds through the year come from both the South-West and South. Snow typically covers the ground from November to mid-April (about 6 months), and its depth is $60-70 \mathrm{~cm}$.

\section{Thermal power plants}

For this study, we selected four urban thermal power plants close to the community infrastructure and residential districts: (i) Omsk coal-fired (TPP-1), (ii) Kemerovo coalfired (TPP-2), (iii) Yurga coal-fired (TPP-3), and (iv) Tomsk fossil fuel (TPP-4) thermal power plants. The characteristics of these thermal power plants are summarized in Table 1, showing operating conditions, stack heights and specification of the fuel type used (open access Internet data). Each TPP has two stacks of different heights (except TPP-4 having the same heights) that can disperse pollutants around TPPs and over large areas with the main wind direction.

The coal used at the studied TPPs contains $\mathrm{Hg}$ as a trace element (Table 1). It is necessary to note that the Russian coal classification system used in this study is based on the technical grade of the coal applied in the energy industry (Russian State Standard 25543-88). The coal of grade D from Kuznetsk Basin (Russia) is used at the TPP-2, TPP-3, and TPP-4, and the coal of grade SS from Ekibastuz Basin (Kazakhstan) is applied at TPP-1. The coal of grade D is used as highreactivity power fuel, while the coal of grade SS belongs to low-reactivity high-ash coals. The predominant energy fuel for the TPP-4 is coal (75-90 \%) and natural gas (10-25\%).

\section{Sampling and sample preparation}

To identify the impact of TPPs on the ambient air quality, the sampling sites were selected in the North-East and the North areas surrounding each plant, according to the prevalent wind direction (Table 2). In these areas, the sampling sites were located at a distance of 0.6 to $4.5 \mathrm{~km}$ from the plant. Additionally, for the selection of sampling locations following factors were considered: (i) extension of emissions depending on

Table 1. Characteristics of urban thermal power plants and fuel type used (large cities in Western Siberia)

\begin{tabular}{|c|c|c|c|c|c|c|c|c|}
\hline \multirow{2}{*}{$\begin{array}{c}\text { Thermal } \\
\text { power } \\
\text { plant in } \\
\text { large cities }\end{array}$} & \multirow{2}{*}{$\begin{array}{c}\text { Thermal } \\
\text { power, } \\
\text { Gcal/ } \\
\text { hour }\end{array}$} & \multirow{2}{*}{$\begin{array}{c}\text { Capacity, } \\
\text { MW }\end{array}$} & \multirow{2}{*}{$\begin{array}{c}\text { Two stack } \\
\text { heights, } \\
\mathrm{m}\end{array}$} & \multirow{2}{*}{$\begin{array}{l}\text { Fuel } \\
\text { type }\end{array}$} & \multicolumn{4}{|c|}{ Specification of coal (Zharov et al. 1996) } \\
\hline & & & & & Grade & Deposit & $A^{d}, \%$ & $\begin{array}{c}\mathrm{Hg} \\
\text { content, } \\
\mathrm{mg} \mathrm{kg}^{-1}\end{array}$ \\
\hline $\begin{array}{c}\text { Omsk } \\
(\mathrm{TPP}-1)\end{array}$ & 1763 & 695 & $\begin{array}{c}180 \text { and } \\
275\end{array}$ & coal & SS & $\begin{array}{c}\text { Ekibastuz } \\
\text { Basin }\end{array}$ & $36-52$ & 0.12 \\
\hline $\begin{array}{c}\text { Kemerovo } \\
\text { (TPP-2) }\end{array}$ & 1540 & 485 & $\begin{array}{c}180 \text { and } \\
210\end{array}$ & coal & D & $\begin{array}{c}\text { Kuznetsk } \\
\text { Basin }\end{array}$ & $7-20$ & 0.08 \\
\hline $\begin{array}{c}\text { Yurga } \\
\text { (TPP-3) }\end{array}$ & 91 & 614 & $\begin{array}{c}58 \text { and } \\
100\end{array}$ & coal & D & $\begin{array}{c}\text { Kuznetsk } \\
\text { Basin }\end{array}$ & $7-20$ & 0.08 \\
\hline $\begin{array}{c}\text { Tomsk } \\
\text { (TPP-4) }\end{array}$ & 815 & 331 & $\begin{array}{l}100 \text { of } \\
\text { each } \\
\text { stack }\end{array}$ & $\begin{array}{c}\text { coal, } \\
\text { natural } \\
\text { gas }\end{array}$ & D & $\begin{array}{c}\text { Kuznetsk } \\
\text { Basin }\end{array}$ & $7-20$ & 0.08 \\
\hline
\end{tabular}

Note: source: data open source; $A^{d}$ - fuel ash content on dry basis 
the operating conditions and stack heights 으 (Russian State Standard for air pollution control RD 52.04.186-89); (ii) flat terrain; (iii) sampling site accessibility; (iv) vicinity of community infrastructure and residential areas; ( $v$ ) distance from roads and other emission sources; (vi) high snow pollution with deposited airborne particles (Osipova et al. 2015). Table 2 demonstrates the sampling site distances from the studied TPPs. In total, samples from 28 sampling sites were collected around the studied plants.

Samples were collected and prepared in accordance with the Russian State Standard for air pollution control (RD 52.04.186-89) and several studies (Williamson et al. 2008; Galitskaya and Rumyantseva 2012; Kasimov et al. 2012; Filimonova et al. 2015; Yanchenko et al. 2015; Grebenshchikova et al. 2017; Taraškevičius et al. 2017; Gustaytis et al. 2018). To obtain the representative data on atmospheric $\mathrm{Hg}$ snow cover deposition rates during the winter season, snow sampling was performed at the end of February, before the beginning of the snowmelt period.

Snow samples were collected from a snow pit, along the vertical profile from the top of the snow pack to at least $5 \mathrm{~cm}$ above the ground in order to avoid sample contamination with soil. Pit size was $45 \times 50 \mathrm{~cm}$. The snow samples were stored in polyethylene bags. Sample weights varied from 17 to $18 \mathrm{~kg}$. This amount of snow was necessary to obtain a sufficient amount of particulate matter deposited in snow. The samples were melted inside of clean closed plastic containers at room temperature. After melting, meltwater was immediately filtered through pre-weighed
1-2.5 um Blue Line cellulose non-ashen filters (Russian State Standard 12026-76 for laboratory filter paper) retaining the solid particles bigger than filter cut-off. Then, the filters with particulate phase were dried at room temperature and, finally weighed. The fraction isolated by this method is called in this work as 'the particulate phase of snow'. The weighing of filter before and after filtering of samples enabled the calculation of particulate load $\left(P_{n}\right)\left(\mathrm{mg} \mathrm{m}^{-2} \mathrm{~d}^{-1}\right)$.

\section{$\mathrm{Hg}$ analysis in the samples}

The particulate phase of snow was analyzed by atomic absorption spectrometry (AAS) with pyrolytic volatilization and scanning electron microscopy (SEM) equipped with an energy dispersive $\mathrm{X}$-ray spectroscopy (EDX) in the laboratories of the Uranium Geology International Centre, Tomsk Polytechnic University (TPU), Russia. The Hg analysis was carried out under dust free conditions.

\section{AAS with pyrolytic volatilization}

The content of $\mathrm{Hg}^{\mathrm{p}}$ in the samples was measured by AAS with pyrolytic volatilization using an atomic absorption spectrometer RA-915+ with pyrolyzer PYRO-915 (Lumex, Russia) and software package RA915R. In samples, Hg compounds were atomized at $850^{\circ} \mathrm{C}$ in a cuvette connected with an open absorption cell. For each sample, $150 \mathrm{mg}$ of particulate phase obtained by filtration method described above was taken for $\mathrm{Hg}$ detection. Three replicate measurements were performed for each sample. From replicates, average contents of $\mathrm{Hg}$ in each sample of the particulate phase of snow (mg

Table 2. Sampling site distances around urban thermal power plants located in cities (Omsk, Tomsk, Kemerovo region, Western Siberia)

\begin{tabular}{|c|c|c|c|c|c|c|c|c|c|c|c|c|}
\hline $\begin{array}{c}\text { Thermal } \\
\text { power } \\
\text { plant }\end{array}$ & \multicolumn{9}{|c|}{ North-east area, km } & \multicolumn{7}{c|}{ North area, km } & $\begin{array}{c}\text { Number of } \\
\text { sampling } \\
\text { sites }\end{array}$ \\
\hline TPP-1 & 0.75 & 1.5 & 3.5 & 4.5 & - & - & 0.75 & 1.5 & 2.0 & - & - & 7 \\
\hline TPP-2 & 0.6 & 1.1 & 1.8 & 2.3 & 2.7 & 3.9 & - & - & - & - & - & 6 \\
\hline TPP-3 & 0.6 & 1.1 & - & - & - & - & 0.6 & 1.2 & 1.8 & - & - & 5 \\
\hline TPP-4 & 0.73 & 1.0 & 1.3 & 1.6 & 2 & - & 0.6 & 0.9 & 1.4 & 1.8 & 2.1 & 10 \\
\hline
\end{tabular}

Note: description of TPPs are given in Table 1 
$\mathrm{kg}^{-1}$ ) were calculated. The detection limit of the method for $\mathrm{Hg}$ quantification in the particulate phase of snow was $0.005 \mathrm{mg} \mathrm{kg}^{-1}$ and analytical precision was within 20-28\%.

\section{SEM-EDX}

SEM-EDX analysis was used to determine Hg-bearing particles in the samples collected at ca. $1 \mathrm{~km}$ to the North-East and the North of each TPP. The selection of the sampling distance is based on the results of our previous study where we observed an accumulation of physically and chemically absorbed mercury in a particulate phase of snow sampled in $1.3 \mathrm{~km}$ from Tomsk fossil fuel thermal power plant (Filimonenko at al. 2014).

Morphological characteristics, size, and element analysis of individual particles were performed by SEM (Hitachi S-3400N SEM, Japan) equipped with an EDX (XFlash 4010 detector, Bruker AXS Microanalysis $\mathrm{GmbH}$, Germany). First, each sample was fixed on a carbon tape with a surface area of $25 \mathrm{~mm}^{2}$ for carbon coating. Then, a very thin film of carbon was deposited on the surface of each sample using the high vacuum method, resulting in electrically conductive samples. The working conditions of SEM measurements were: $20 \mathrm{kV}$ accelerating voltage, $30 \mathrm{~s}$ spectral acquisition time, and $10 \mathrm{~mm}$ working distance. SEM images were acquired at a magnification of 500x. EDAX Esprit software was used for the quantitative analysis of individual particles. The weight percent of each element was determined from the EDX spectrum. To reveal Hg-bearing particles, approximately 150 particles were analyzed in each sample.

\section{Data analysis}

STATISTICA 8.0 software was used to calculate the mean values and standard deviations as well as to reveal the statistically significant differences between groups applying the Kruskal-Wallis non-parametric test (when comparing more than two groups).

Following indexes were calculated to assess $\mathrm{Hg}^{\mathrm{P}}$ snow cover pollution:
The concentration coefficient representing the level of element enrichment in the particulate phase of snow in relation to the background content was determined using equation 1 (Galitskaya and Rumyantseva 2012; Kasimov et al. 2012; Filimonova et al. 2015; Taraškevičius et al. 2017; Gustaytis et al. 2018):

$K_{c}=\frac{C_{i}}{C_{b}}$

where, $K_{c}$ is the concentration coefficient; $C_{i}$ is the element content in the particulate phase of snow $\left(\mathrm{mg} \mathrm{kg}^{-1}\right) ; C_{b}$ is the background element content in the particulate phase of snow $\left(\mathrm{mg} \mathrm{kg}^{-1}\right)$. The background content of $\mathrm{Hg}$ in the particulate phase under Western Siberia conditions (IAO SB RAS at Fonovaya Observatory (Antonovich et al. 2018)) equals $0.08 \mathrm{mg} \mathrm{kg}^{-1}$ (Talovskaya et al. 2012).

The element load was calculated to evaluate the atmospheric $\mathrm{Hg}^{\mathrm{p}}$ depositional flux (equations 2-3) (Galitskaya and Rumyantseva 2012; Kasimov et al. 2012; Filimonova et al. 2015; Taraškevičius et al. 2017; Gustaytis et al. 2018):

$E_{l}=C_{i} \times P_{n}$

$P_{n}=\frac{P_{o}}{S \times t}$

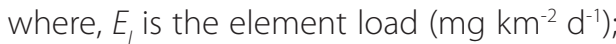
$C$ is the element content in the particulate phase of snow $\left(\mathrm{mg} \mathrm{kg}^{-1}\right) ; P_{n}$ is the particulate load ( $\left.\mathrm{mg} \mathrm{m}^{-2} \mathrm{~d}^{-1}\right) ; P$ is the mass of the particulate phase $(\mathrm{mg}) ; S$ is the square of snow pit $\left(\mathrm{m}^{2}\right)$; $\mathrm{t}$ is the time representing the stable snow cover formation duration up to sampling day (d).

The coefficient of element load is shown as the ratio of element load to the background element load (equation 4) (Kasimov et al. 2012):

$K_{p}=\frac{E_{l}}{E_{l b}}$

where, $K_{p}$ is the coefficient of element load; $E_{l b}$ is the background element load. The background $\mathrm{Hg}$ load under Western Siberia conditions (IAO SB RAS at Fonovaya Observatory (Antonovich et al. 2018)) equals $1.2 \mathrm{mg} \mathrm{km}^{-2} \mathrm{~d}^{-1}$ (Talovskaya et al. 2012). 
The enrichment factor (EF) of element in particulate phase of snow relative to the Earth's crust (Shevchenko et al. 2003), was calculated using equation 5 :

$$
E F=\frac{\left(C_{i} / C_{S c}\right) \text { particulatephaseofsnow }}{\left(C_{i} / C_{S c}\right)}
$$

where, $C_{i}$ is the element content $\left(\mathrm{mg} \mathrm{kg}^{-1}\right) ; C_{s c}$ is the scandium content $\left(\mathrm{mg} \mathrm{kg}^{-1}\right)$.

Usually, Al, Si, Ti, Sc or Fe are used as reference elements, since crustal material contains these elements in high amounts, they are characterized by low occurrence variability, and are not significantly affected by contamination (Saur and Juste 1994). In this study, Sc was chosen as the reference element for the EF calculation. The content of Sc (15.6 mg kg-1) and $\mathrm{Hg}\left(0.065 \mathrm{mg} \mathrm{kg}^{-1}\right)$ in Earth's crust was chosen from the study of Grigor'ev (2009). The content of Sc in the particulate phase of snow was measured by instrumental neutron activation analysis (neutron research reactor IRT-T in the PhysicalTechnical Institute of TPU, $\gamma$-spectrometer Canberra with Ge-detector, USA) in the laboratory of Uranium Geology International Centre, TPU.

It can be stated that, if $K_{c^{\prime}} K_{p^{\prime}}$ and EF values are higher than 1, mercury could be of anthropogenic origin.

\section{RESULTS}

$\mathrm{Hg}$ in the particulate phase of snow samples

Table 3 shows the statistical evaluation for $\mathrm{Hg}$ content in the particulate phase of snow. The contents of $\mathrm{Hg}$ in the samples collected around TPP-1, TPP-2 and TPP4 were statistically compared with each other (Kruskal-Wallis test, $\mathrm{p} \geq 0.1$ ). However, statistically slightly higher $\mathrm{Hg}$ contents were observed in the samples around TPP1 than in those around TPP-3 (Kruskal-Wallis test, $0.1>p \geq 0.05)$. Moreover, $\mathrm{Hg}$ contents were significantly higher within the studied area of TPP-4 than in those within the studied area of TPP-3 (Kruskal-Wallis test, $0.05>p \geq 0.01$ ). Furthermore, $\mathrm{Hg}$ contents did not significantly differ in the samples from TPP-2 and TPP-3 areas.

Calculation of $K$ showed that Hg contents exceeded background value more than two for the samples collected at the studied TPP-1, TPP-2 and TPP-4 areas, whereas $\mathrm{Hg}$ contents were about two times higher than the background value in the samples from TPP-3 area (Table 4).

Table 4 also demonstrates the mean values and range of EFs for $\mathrm{Hg}$ in the particulate phase of snow. EF values for $\mathrm{Hg}$ were higher than one, indicating that this element was enriched relative to the Earth's crust. In addition, EF of $\mathrm{Hg}$ was higher for the samples collected around TPP-4 than for those around other plants.

\section{Atmospheric $\mathrm{Hg}^{P}$ depositional flux}

Fig 2. presents the variations of mean $\mathrm{Hg}$ load, $E_{\mu}$ indicating the rates of atmospheric $\mathrm{Hg}$ depositional fluxes. The $\mathrm{Hg}$ load around TPP-3 ranged from 17.2 to $191 \mathrm{mg} \mathrm{km}^{-2}$ $\mathrm{d}^{-1}$ with a mean $73.1 \pm 32.2 \mathrm{mg} \mathrm{km}^{-2} \mathrm{~d}^{-1}$,

Table 3. Statistical summary of $\mathrm{Hg}$ content in particulate phase of snow around urban thermal power plants located in large cities of Western Siberia

\begin{tabular}{|c|c|c|c|c|}
\hline \multirow{2}{*}{$\begin{array}{c}\text { Thermal power } \\
\text { plant }\end{array}$} & \multicolumn{4}{|c|}{ Hg content in particulate phase of snow $\left(\mathrm{mg} \mathrm{kg}^{-1}\right)$} \\
\cline { 2 - 5 } & Mean \pm SD & Median & Min & Max \\
\hline TPP-1 & $0.205 \pm 0.028$ & 0.196 & 0.179 & 0.246 \\
\hline TPP-2 & $0.173 \pm 0.019$ & 0.165 & 0.156 & 0.203 \\
\hline TPP-3 & $0.139 \pm 0.045$ & 0.125 & 0.098 & 0.210 \\
\hline TPP-4 & $0.194 \pm 0.032$ & 0.199 & 0.126 & 0.238 \\
\hline
\end{tabular}

Note: SD - standard deviation; description of TPPs are given in Table 1 
Table 4. Concentration coefficient $\left(K_{c}\right)$, coefficient load $\left(K_{p}\right)$ and enrichment factor (EF) of $\mathrm{Hg}$ in the particulate phase of snow around urban thermal power plants located in large cities of Western Siberia

\begin{tabular}{|c|c|c|c|c|c|c|c|c|c|}
\hline \multirow{2}{*}{ Thermal power plant } & \multicolumn{4}{|c|}{$K_{c}$} & \multicolumn{3}{c|}{$K_{p}$} & \multicolumn{3}{c|}{$E F$} \\
\cline { 2 - 11 } & Mean & Min & Max & Mean & Min & Max & Mean & Min & Max \\
\hline TPP-1 & 2.5 & 2.2 & 3.1 & 34.1 & 22.5 & 62.9 & 2.3 & 1.8 & 2.9 \\
\hline TPP-2 & 2.1 & 1.9 & 2.5 & 35.8 & 20.0 & 46.2 & 2.6 & 2.2 & 3.1 \\
\hline TPP-3 & 1.7 & 1.2 & 2.6 & 60.9 & 14.3 & 159 & 1.6 & 1.1 & 3.7 \\
\hline TPP-4 & 2.4 & 1.6 & 3.0 & 5.5 & 2.5 & 8.4 & 4.3 & 3.3 & 5.1 \\
\hline
\end{tabular}

Note: description of TPPs are given in Table 1

which was higher than the mean $\mathrm{Hg}$ load determined within the studied area of other plants. The lowest value for El (range: $3.0-10.1 \mathrm{mg} \mathrm{km}^{-2} \mathrm{~d}^{-1}$, mean: $6.6 \pm 2.0 \mathrm{mg} \mathrm{km}^{-2} \mathrm{~d}^{-1}$ ) was observed around TPP-4 which was significantly lower than the values determined for other studied TPP areas (Kruskal-Wallis test, $0.01>p \geq 0.001)$. The Hg load around TPP-1 ranged from 20.8 to $75.5 \mathrm{mg} \mathrm{km}^{-2} \mathrm{~d}^{-1}$, with mean value of $41.5 \pm 20.0 \mathrm{mg} \mathrm{km}^{-2} \mathrm{~d}^{-1}$. The
$\mathrm{Hg}$ load within the studied area of TPP-2 varied from 24.0 to $55.4 \mathrm{mg} \mathrm{km}^{-2} \mathrm{~d}^{-1}$, with a mean value of $42.9 \pm 11.5 \mathrm{mg} \mathrm{km}^{-2} \mathrm{~d}^{-1}$.

The coefficients of $\mathrm{Hg}$ load, $K_{p^{\prime}}$ calculated according to equation 4 , are given in Table 4. The $K_{p}$ values showed that the $\mathrm{Hg}$ load determined for the areas around the studied TPPs exceeded the background values several times. The mean values of $K_{p}$ increased in the following order: TPP-4

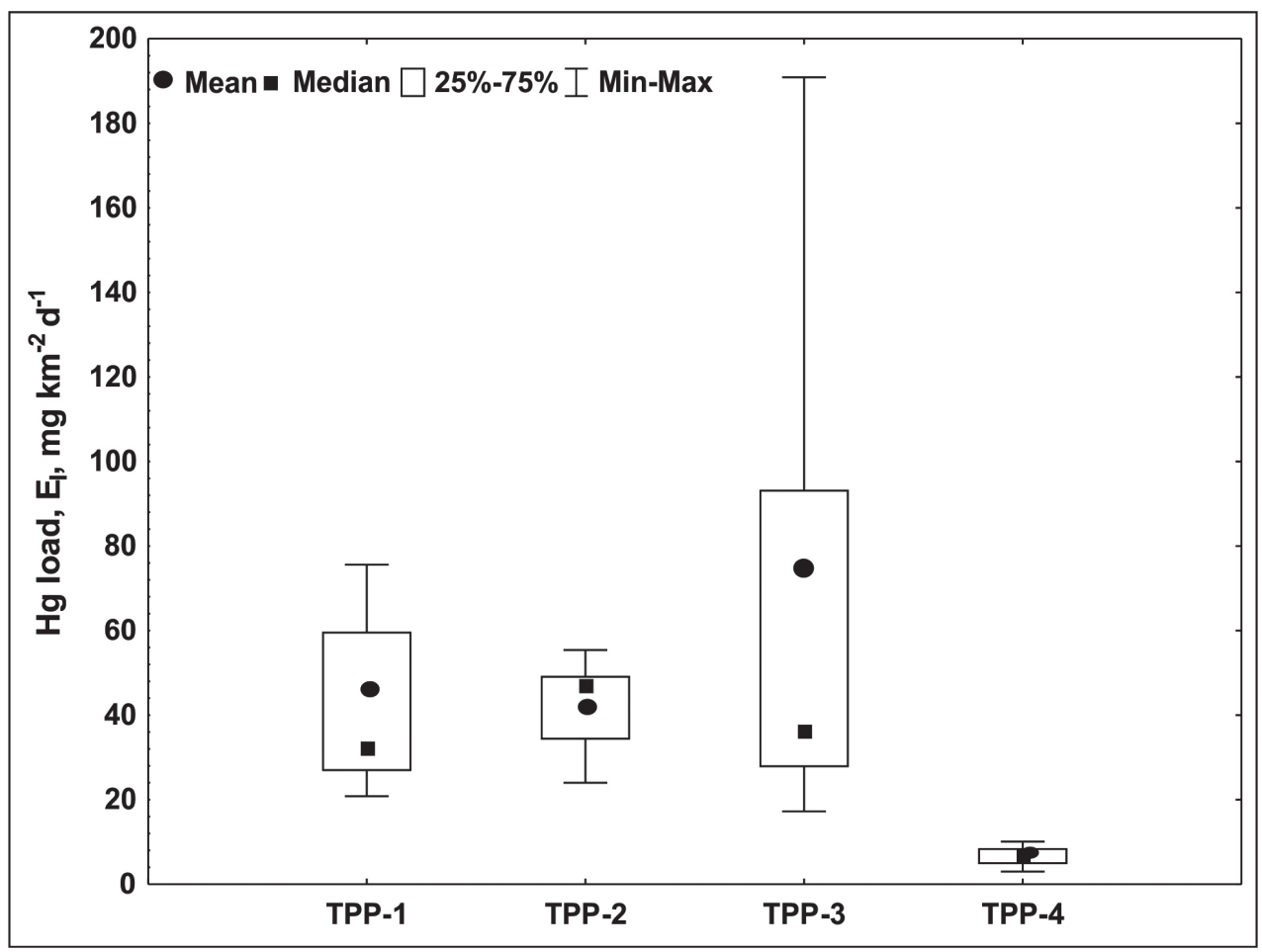

Fig. 2. Box plot of $\mathrm{Hg}$ load around urban thermal power plants located in large cities of Western Siberia (note: description of TPPs are given in Table 1) 
$<\mathrm{TPP}-1 \approx \mathrm{TPP}-2<\mathrm{TPP}-3$. This indicates that the $\mathrm{Hg}$ load around TPP-3, relative to the background value, was higher than in the areas around other plants.

The Hg load mainly depends on the value of particulate load, $P_{n}$ (Fig. 3). The mean values of $P_{n}$ increased in the following order: TPP4 (34.2 $\left.\mathrm{mg} \mathrm{m}^{-2} \mathrm{~d}^{-1}\right)<$ TPP-1 (201 $\mathrm{mg} \mathrm{m}^{-2} \mathrm{~d}^{-1}$ ) $<$ TPP-2 (248 $\left.\mathrm{mg} \mathrm{m}^{-2} \mathrm{~d}^{-1}\right)<$ TPP-3 (555 mg $\left.\mathrm{m}^{-2} \mathrm{~d}^{-1}\right)$. This shows that the largest $P_{n}$ was identified around TPP-3, while the smallest one was found around TPP-4. Additionally, the values of particulate load within the studied area of TPP-3 varied stronger (133$1527 \mathrm{mg} \mathrm{m}^{-2} \mathrm{~d}^{-1}$ ) compared to other TPPs.

$\mathrm{Hg}$-bearing particles in the particulate phase of snow samples

SEM-EDX measurements revealed the presence of Hg-bearing particle only in the particulate phase of snow sample collected at $0.5 \mathrm{~km}$ from TPP-3 (Fig. 4). Such particles were not detected in the samples collected around other studied TPPs.
Fig. 4 demonstrates the SEM photomicrograph (a) and EDX spectra (b) of the identified $\mathrm{Hg}$-bearing particle. This particle exhibited uneven shape with $1.2 \times 0.7 \mu \mathrm{m}$ size. Based on the chemical information derived from EDX (Fig. 4, b), the identified particle was composed of $\mathrm{Hg}$ and $\mathrm{S}$. Furthermore, the emission spectrum of elements showed a high content of $\mathrm{O}$ and traces of $\mathrm{Si}, \mathrm{Al}, \mathrm{Na}, \mathrm{K}$, $\mathrm{Fe}$, and $\mathrm{Ca}$ which most likely originated from the nearby large particle. The presence of these elements in the large particle indicates that this particle represents an aggregate of alumosilicate minerals (Fig. 4, c).

\section{DISCUSSION}

The $\mathrm{Hg}$ content determined in the particulate phase of snow samples and atmospheric $\mathrm{Hg}$ depositional fluxes showed that $\mathrm{Hg}$ can be present in the snow cover around the urban thermal power plants irrespective of their operating conditions (capacity and thermal power) and fuel type used. The calculated indexes $\left(K_{d} K_{p}\right.$ and $\left.E F\right)$ were higher than one, indicating the anthropogenic origin of $\mathrm{Hg}$ in the studied areas.

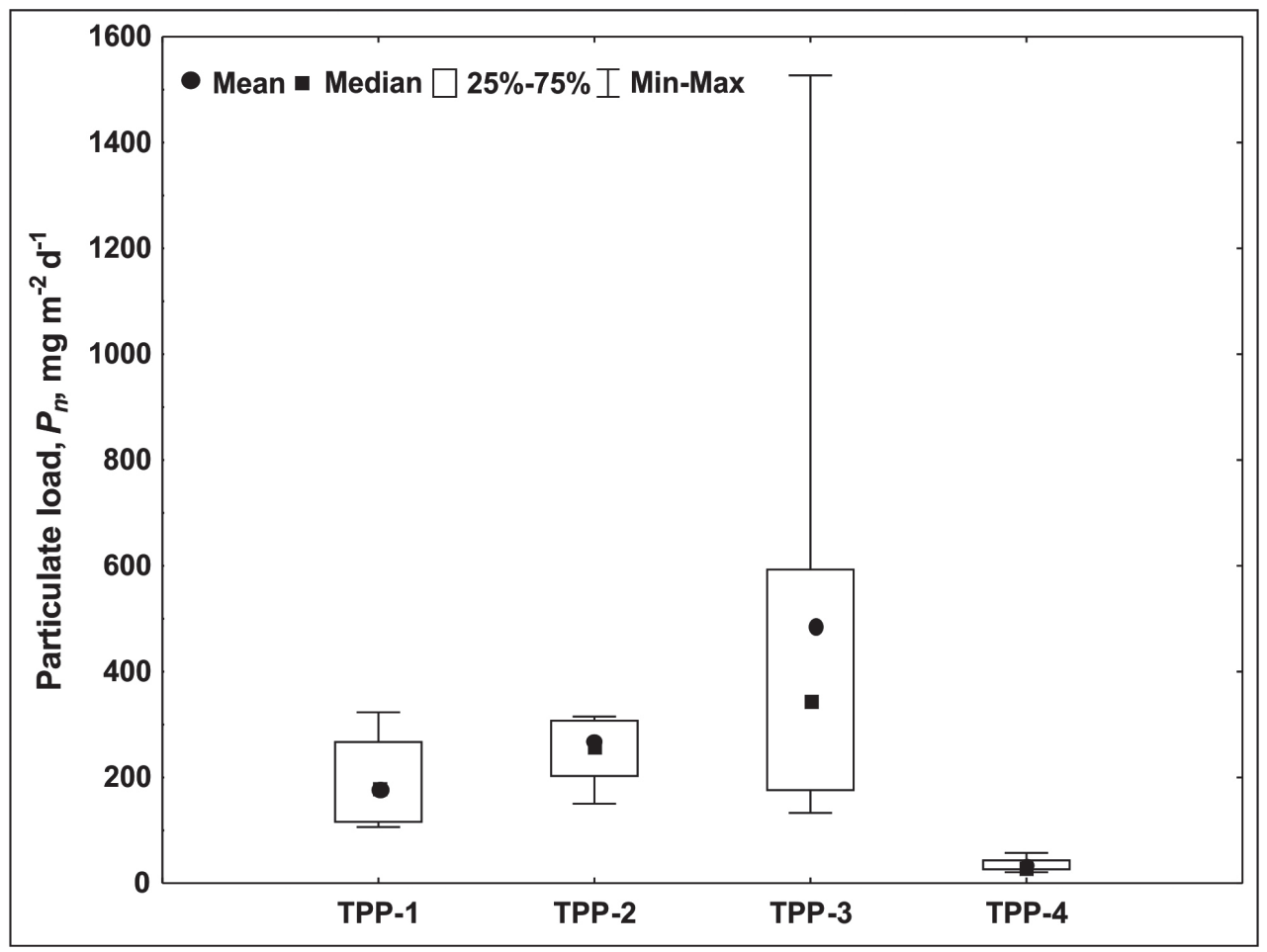

Fig. 3. Box plot of particulate load around urban thermal power plants located in large cities of Western Siberia (note: description of TPPs are given in Table 1) 


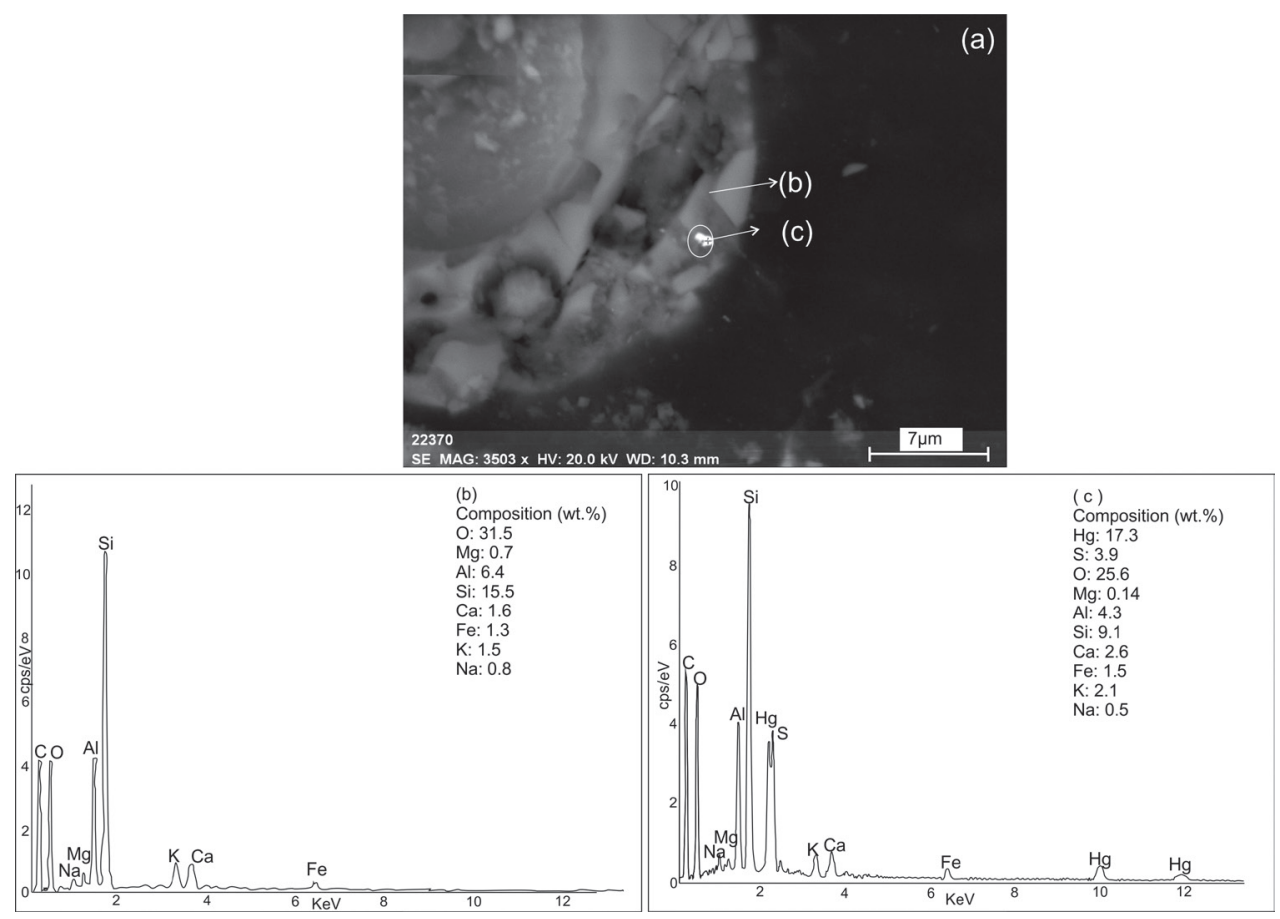

Fig. 4. SEM photomicrograph (a) and EDX spectra of alumosilicate particle (b) and $\mathrm{Hg}$-bearing particle (c) in particulate phase of snow collected around the coal-fired thermal power plant

Mercury exists in the air in one of three states, which are gaseous elemental mercury $\left(H g^{0}\right)$, reactive gaseous mercury in divalent form $\left(\mathrm{Hg}^{2+}\right)$ and particulate mercury $\left(\mathrm{Hg}^{\mathrm{P}}\right)$. The elemental $\mathrm{Hg}^{0}$ can remain in the air longer (0.5-2 years) and can be transported over long distances, transforming later into soluble divalent forms, and then deposited (Schroeder and Munthe 1998).

The content of $\mathrm{Hg}$ in the particulate phase of snow determined in this study could confirm the suggestions about high sorption of gaseous $\mathrm{Hg}$ species, $\mathrm{Hg}^{2+}$, and $\mathrm{Hg}^{\mathrm{P}}$ on airborne particles at low ambient temperatures (Kim et al. 2012), effective scavenging by winter precipitation, and finally deposition in snow (Siudek et al. 2014). In addition, Kim et al. (2012) demonstrated that the fine particles $(<1.8 \mu \mathrm{m})$ of atmospheric $\mathrm{Hg}^{\mathrm{P}}$ were dominated in the winter season.

It was surprising to identify that there were no statistically significant differences of $\mathrm{Hg}$ content in the samples collected in the areas around TPP-1, TPP-2 and TPP-4, despite their different operating conditions and fuel type used. This fact may indicate that high thermal power (815-1763 Gcal/ hour) characteristic for these three TPPs influences the high $\mathrm{Hg}$ content in the particulate phase of snow (0.173-0.205 $\mathrm{mg} \mathrm{kg}^{-1}$ ), regardless of different capacity, stack heights, and coal origin (Table 1). The low $\mathrm{Hg}$ content, identified in the samples around TPP-3, could be explained by smaller thermal power (91 Gcal/hour) than those for other studied TPPs.

Although $\mathrm{Hg}$ content in the coal is low (Table 1), this element could be released during coal combustion with the exhaust gases from the stacks into the air. From the literature it is known that $98 \%$ of $\mathrm{Hg}$ in similar exhaust gases appears as $\mathrm{Hg}^{0}, \mathrm{HgO}$, and $\mathrm{CH}_{3} \mathrm{Hg}$ (Xu et al. 2003). Additionally, in the flue gas, $\mathrm{Hg}^{0}$ is partly converted to $\mathrm{Hg}^{2+}$ by oxidation and is also partly associated with fly ash particles $\left(\mathrm{Hg}^{\mathrm{P}}\right)$. After emission, $\mathrm{Hg}^{\mathrm{P}}$ and $\mathrm{Hg}^{2+}$ can be deposited around their anthropogenic emission sources (Galbreath and Zygarlicke 2000), i.e. thermal power plants. Results of Hg measurements in the 
air within Tomsk indicated that one of total $\mathrm{Hg}$ sources was the emissions of fossil fuel thermal power plant (Lyapina et al. 2009).

High EF values of $\mathrm{Hg}$ determined for the particulate phase of snow around TPP-4 could be affected not only by combustion of coal representing $75-90 \%$ of total fuel used in this TPP but also by natural gas corresponding to the rest of $10-25 \%$. Mercury is often presented in natural gas as a trace element and can be emitted during high temperature combustion (Wilhelm 2001).

Open coal warehouses located in the territory of each studied thermal power plant could be considered as an additional source of $\mathrm{Hg}^{\mathrm{P}}$ mainly due to the possible transport of coal aggregates from these warehouses by the wind at long distances. Considering the locations of studied TPPs in urban areas, close to residential districts, the exhausts of $\mathrm{Hg}$ from vehicle traffic cannot be excluded. Some studies have indicated that vehicle exhausts slightly contribute to $\mathrm{Hg}$ deposition in snow cover (Siudek et al. 2014; Zhang et al. 2013).

Based on the results obtained, the $\mathrm{Hg}$ contents measured in the particulate phase of snow samples and atmospheric $\mathrm{Hg}^{\mathrm{P}}$ depositional fluxes can be used as markers for $\mathrm{Hg}$ source identification, specifically for combustion of coal from the Kuznetsk Basin. However, more investigations are needed to determine content markers in the samples collected around TPPs using coal from the Ekibastuz Basin and from other origins.

In addition, the correlation between the $\mathrm{Hg}$ load and characteristics of TPPs (Table 1) was not observed. The data indicated that the $\mathrm{Hg}$ load is predominantly affected by values of particulate load than by $\mathrm{Hg}$ content in the samples. The following correlation was observed: (1) the lower value of the particulate load and the higher value of the $\mathrm{Hg}$ content formed the lowervalue of the $\mathrm{Hg}$ load; (2) the higher value of the particulate load and the lower value of the Hg content formed the higher value of the $\mathrm{Hg}$ load. The first observed dependence could indicate a significant $\mathrm{Hg}$ accumulation in a small mass of particulate phase of snow, while the second dependence could be a result of $\mathrm{Hg}$ spread in a large mass of particulate phase. The highest values of particulate load is due to the low efficiency of the capture systems to retain emitted gases and particulate matter, as well as due to the extended coal dust distribution in the main wind direction from the open coal warehouses located in the plant territory.

Individual particle analysis by SEM-EDX identified anthropogenic Hg-bearing particle in the form of $\mathrm{HgS}$ in the particulate phase of snow collected in the vicinity of TPP-3. Most likely the HgS was originated from coal and was emitted during combustion into the atmosphere. The HgS was already observed as a minor phase in Siberian coal (Arbuzov et al. 2015). The fact that the Hg containing particle was observed only in one sample can be explained by the generally low $\mathrm{Hg}$ contents in the particulate phase of snow. The concentration range of $0.139-0.205 \mathrm{mg} \mathrm{kg}^{-1}$ or 139 - 205 ng g $^{-1}$ determined for Hg contents in the particulate phase of snow is too low to find enough Hg-bearing particles in the samples using SEM measurements. At this content range, a lot of SEM photos and consequently large measurement times are needed. An attachment of the $\mathrm{Hg}$-bearing particles to the aluminosilicate phases during the filtration of snow melting water cannot be fully excluded. Due to the small size of the $\mathrm{Hg}$-bearing particle, it belongs to the fine particulate matter (Pope and Dockery 2006). If this Hg-bearing particle was suspended in the air as an individual particle not bound to the aluminosilicates, it could be in this case inhaled and remained in respiratory organs such as lungs.

\section{CONCLUSIONS}

The presence of mercury in the particulate phase of snow cover around the thermal power plants determined in this study allowed new insights on $\mathrm{Hg}$ occurrence. Higher $\mathrm{Hg}$ concentration coefficient and coefficient of load observed in relation to the background values, as well as high $\mathrm{Hg}$ enrichment factors determined relative to the mean $\mathrm{Hg}$ content in the Earth's crust 
indicated the clear contribution of thermal power plants to the pollution of snow by anthropogenic $\mathrm{Hg}^{\mathrm{P}}$. Furthermore, our results clearly indicated the importance of $\mathrm{Hg}$ monitoring in the particulate phase of snow in the areas impacted by the thermal power plant for the evaluation of particulate $\mathrm{Hg}$ budget in such urban areas in the winter season.

The results showed that the mean $\mathrm{Hg}$ content in the particulate phase of snow samples was similar for the areas surrounding TPPS, which have high thermal power and use different fuel types. TPP with low thermal power contributed to low $\mathrm{Hg}$ contents in particulate matter deposits. Furthermore, we did not observe any correlation between $\mathrm{Hg}$ content in the samples and the capacity of TPPS. It was found that particulate load was a key factor for the variability of atmospheric $\mathrm{Hg}$ deposition fluxes determined in the areas around urban TPPs. The relationship between atmospheric $\mathrm{Hg}$ depositional fluxes and thermal power plant characteristics was not observed.

The obtained data showed that $\mathrm{Hg}$ was derived from anthropogenic sources, including emissions from TPPs and possibly long-range transport from open coal warehouses located in the territory of the plants.

Based on the size, shape, and element composition, the $\mathrm{Hg}$-bearing particle identified by SEM-EDX measurements can be considered as non-mineral type, possibly of anthropogenic origin. The $\mathrm{Hg}$ content in the particulate phase of snow and the atmospheric $\mathrm{Hg}$ depositional fluxes can be considered as effective pollution markers for the identification of coal combustion emission sources.

The results obtained in the present study providing reliable data for human health risk assessment are essential for further environmental studies, and can also be applicable to other urban areas worldwide, being impacted by coal-fired thermal power plants.

\section{ACKNOWLEDGEMENTS}

The experimental procedures were carried out at Tomsk Polytechnic University within the framework of Tomsk Polytechnic University Competitiveness Enhancement Program Grant in the Group of Top Level World Research and Academic Institutions. This work was partially supported by the Russian Foundation for Basic Research (grant number 16-45-700184p_a, 2016-2018) and in the framework of the state budget theme No. AAAA-A17-117013050031-8. We are grateful Sergey llenok for his assistance in SEM-EDX analysis and Ekaterina Filimonenko for her help in Hg measurements (Uranium Geology International Centre, TPU), Raisa Abramova and Muriel Whitchurch for their comments during the manuscript preparation.

\section{REFERENCES}

Antonova A.M., Vorobev A.V., Vorobev V.A., Dutova E.M., Pokrovskiy V.D. (2019). Modelling distribution of contaminating substances of electric power emissions in the atmosphere on the basis of the SKAT programming complex. Bulletin of the Tomsk Polytechnic University, Geo Assets Engineering, 330(6), pp. 174-186.

Antonovich V.V., Antokhin P.N., Arshinov M.Y., Belan B.D., Balin Y.S., Davydov D.K., Ivlev G.A., Kozlov A.V., Kozlov V.S., Kokhanenko G.P., Novoselov M.M., Panchenko M.V., Penner I.E., Pestunov D.A., Savkin D.E., Simonenkov D.V., Tolmachev G.N., Fofonov A.V., Chernov D.G., Smargunov V.P., Yausheva E.P., Paris J.-D., Ancellet G., Law K.S., Pelon J., Machida T., and Sasakawa M. (2018). Station for the comprehensive monitoring of the atmosphere at Fonovaya Observatory, West Siberia: Current status and future needs. In: Proc. of SPIE, 24th International Symposium on Atmospheric and Ocean Optics: Atmospheric Physics, Volume 10833. Available at: https://doi.org/10.1117/12.2504388 
Arduzov S.I., Osipova N.A., Zaitseva O.P. and Belaya E.V. (2015). Geochemistry of Hg in Siberian coals. In: Proc. of $2 d$ International symposium on mercury in biosphere: Ecological and geochemical approach, held 21-25 September 2015 in Novosibirsk, Russia, pp. 27-31 (in Russian)

Baltrènaitè E., Baltrènas P., Lietuvninkas A., Šerevičienè V. and Zuokaitė E. (2014). Integrated evaluation of aerogenic pollution by air-transported heavy metals ( $\mathrm{Pb}, \mathrm{Cd}, \mathrm{Ni}, \mathrm{Zn}, \mathrm{Mn}$ and $\mathrm{Cu}$ ) in the analysis of the main deposit media. Environmental Science and Pollution Research, 21, pp. 299-313.

Boutron C.F., Vandal G.M., Fitzgerald W.F. and Ferrari C.P. (1998). A forty year record of mercury in central Greenland snow. Geophysical Research Letters, 25, pp. 3315-3318.

Brzezinska-Paudyn A., Van Loon J.C. and Balicki M.R. (1986). Multielement analysis and mercury speciation in atmospheric samples from the Toronto area. Water, Air, \& Soil Pollution, 27, pp. 45-56.

Davidson C.I., Bergin M.H., and Kuhn H.D. (1996). The deposition of particles and gases to ice sheets. In: E.R. Wolff, R.C. Bales, ed., Chemical exchange between the atmosphere and polar snow, Berlin: Springer. NATO ASI Series I, 43, pp. 275-306.

Douglas T.A., Sturm M., Blum J.D., Polashenski C., Stuefer S., Hiemstra C., Steffen A., Filhol S. and Prevost R. (2017). A pulse of mercury and major ions in snowmelt runoff from a small Arctic Alaska Watershed. Environmental Science \& Technology, 51, pp. 11145-11155.

Ferrari C.P., Dommergue A., Veysseyre A., Planchon F. and Boutron C.F. (2002). Mercury speciation in the French seasonal snow cover. Science of the Total Environment, 287(1-2), pp. 61-69.

Filimonenko E.A., Lyapina E.E., Talovskaya A.V. and Parygina I.A. (2014). Eco-geochemical peculiarities of mercury content in solid residue of snow in the industrial enterprises impacted areas of Tomsk. In: Proc. of SPIE 9292, 20th International Symposium on Atmospheric and Ocean Optics: Atmospheric Physics, Volume 929231. Available at: https:// doi.org/10.1117/12.2075637

Filimonova L.M., Parshin A.V., and Bychinskii V.A. (2015) Air pollution assessment in the area of aluminum production by snow geochemical survey. Russian Meteorology and Hydrology, 40 (10), pp. 691-698.

Fitzgerald W.F., Mason R.P., and Vandal G.M. (1991). Atmospheric cycling and air-water exchange of mercury over mid-continental lacustrine regions. Water, Air, \& Soil Pollution, 56, pp. $745-764$.

Galbreath K.C. and Zygarlicke C.J. (2000). Mercury transformation in coal combustion flue gas. Fuel Processing Technology, 65-66, pp. 289-310.

Galitskaya I.V. and Rumyantseva N.A. (2012). Snow-cover contamination in urban territories (Lefortovo district Moscow). Annals Glaciology, 53 (61), pp. 23-26.

Gao Y., Yang C., Maa J. and Yinc M. (2018). Characteristics of the trace elements and arsenic, iodine and bromine species in snow in east-central China. Atmospheric Environment, 174, pp.43-53. 
Gratz L.E. and Keeler G.J. (2011). Sources of mercury in precipitation to Underhill, VT. Atmospheric Environment, 45, pp. 5440-5449.

Grebenshchikova V.I., Efimova N.V., and Doroshkov A.A. (2017). Chemical composition of snow and soil in Svirsk city (Irkutsk Region, Pribaikal'e). Environmental Earth Sciences, 76 (20), pp. 712.

Grigor'ev N.A. (2009). Distribution of chemical elements in the upper continental crust. Yekaterinburg: UrO RAN (in Russian)

Gustaytis M.A., Myagkaya I.N., and Chumbaev A.S. (2018.) Hg in snow cover and snowmelt waters in high-sulfide tailing regions (Ursk tailing dump site, Kemerovo region, Russia). Chemosphere, 202, pp. 446-459.

Huang J., Kang S., Guo J., Sillanpaa M., Zhang Q., Qin X., Du W. and Tripathee L. (2014). Mercury distribution and variation on a high-elevation mountain glacier on the northern boundary of the Tibetan Plateau. Atmospheric Environment, 96, pp. 27-36.

Kasimov N.S., Kosheleva N.E., Vlasov D.V. and Terskaya E.V. (2012). Geochemistry of snow cover within the eastern district of Moscow. Vestnik Moskovskogo Unviersiteta, Seriya Geografiya. 4, pp. 14-24 (in Russian with English summary)

Kim P-R., Han Y-J., Holsen T.M. and Yic S-M. (2012). Atmospheric particulate mercury: Concentrations and size distributions. Atmospheric Environment, 61, pp. 94-102.

Lyapina E.E., Golovatskaya E.A., Ippolitov I.I. (2009). Investigation of mercury content in natural objects of West Siberia. Contemporary Problems of Ecology, 2(1), pp. 1-5.

Marusczak N., Larose C., Dommergue D., Yumvihoze E., Lean D., Nedjai R. and Ferrari C. (2011). Total mercury and methylmercury in high altitude surface snow from the French Alps. Sci. Science of the Total Environment, 409, pp. 3949-3954.

Nelson S.J., Fernandez I.J., and Kahl J.S. (2010). A review of mercury concentration and deposition in snow in eastern temperate North America. In: Hydrological Processes Special Issue: Eastern Snow Conference, 24 (14), pp. 1971-1980. Available at: https://doi. org/10.1002/hyp.7660

Nelson S.J., Johnson K.B., Kahl J.S., Haines T.A. and Fernandez I.J. (2007). Mass balances of mercury and nitrogen in burned and unburned forested watersheds at Acadia National Park, Maine, USA. Environmental Monitoring and Assessment, 126, pp. 69-80.

Osipova N.A., Filimonenko K.A., Talovskaya A.V. and Yazikov E.G. (2015). Geochemical approach to human health risk assessment of inhaled trace elements in the vicinity of industrial enterprises in Tomsk, Russia. Human and Ecological Risk Assessment, 21, pp. 1664-1685.

Pope C.A. and Dockery D.W. (2006). Health effects of fine particulate air pollution: Lines that connect. Journal of the Air \& Waste Management Association, 56(6), pp. 709-742.

Raputa V.F., Kokovkin V.V., Shuvaeva O.V. and Morozov S.V. (2010). Experimental study and numerical analysis of the pollution in the area of highway according to the snow cover composistion. In: Proc. of International Conference on Energy and Development, Environment and Biomedicine, pp. 104-108. 
Russian State Standard 12026-76 for Laboratory filter paper. Specifications. Available at: http://meganorm.ru/Data2/1/4294838/4294838884.pdf [Accessed 15 January 2013] (in Russian)

Russian State Standard 25543-88. Brown coals, hard coals and anthracites. Classification according to genetic and technological parameters. Available at: http://www.internet-law. ru/gosts/gost/7460 [Accessed 15 July 2018] (in Russian)

Russian State Standard for air pollution control. RD 52.04.186-89. Available at: http://docs. cntd.ru/document/1200036406 [Accessed 15 Dec. 2012] (in Russian)

Saur E. and Juste C. (1994). Enrichment of trace elements from long-range aerosol transport in sandy podzolic soils of Southwest France. Water, Air, \& Soil Pollution, 73, pp. 235-246.

Schroeder W.H. and Munthe J. (1998). Atmospheric mercury an overview. Atmospheric Environment, 32, pp. 809-822.

Shevchenko V., Lisitzin A., Vinogradova A. and Stein R. (2003). Heavy metals in aerosols over the seas of the Russian Arctic. Science of the Total Environment, 306 (1-3), pp. 11-25.

Siudek P. (2016). Distribution and variability of total mercury in snow cover - a case study from a semi-urban site in Poznan. Poland. Environmental Science and Pollution Research, 23, pp. 24316-24326.

Siudek P., Falkowska L., Frankowski M. and Siepak J. (2014). An investigation of atmospheric mercury accumulated in the snow cover from the urbanized coastal zone of the Baltic Sea, Poland. Atmospheric Environment, 95, pp. 10-19.

Talovskaya A.V., Filimonenko E.A., Osipova N.A., Lyapina E.E. and Yazikov E.G. (2014). Toxic elements (As, Se, Cd, Hg, Pb) and their mineral and technogenic formations in the snow cover in the vicinity of the industrial enterprises of Tomsk. XVIII International Scientific Symposium in Honour of Academician M. A. Usov: PGON2014 IOP Publishing IOP Conference Series of Earth Environment Scicience, Volume 21, 012042. Available at: https://doi.org/10.1088/1755e1315/21/1/012042

Talovskaya A.V., Filimonenko E.A., Osipova N.A. and Yazikov E.G. (2012). Mercury in dust aerosols in the territory of Tomsk. Safety in Technosphere, 2, pp. 30-34 (in Russian with English summary).

Taraškevičius R., Zinkut R., Gedminien L., Stankevičius Z. (2018). Hair geochemical composition of children from Vilnius kindergartens as an indicator of environmental conditions. Environmental Geochemistry and Health, 40(5), pp. 1817-1840.

Tchounwou P.B., Ayensu W.K., Ninashvili N. and Sutton D. (2003). Review: environmental exposure to mercury and its toxicopathologic implications for public health. Environmental toxicology, 18 (3), pp. 149-175.

UNEP. (2013). Global mercury assessment 2013: sources, emissions, releases and environmental transport, UNEP Chemicals Branch, Geneva, Switzerland

Wiener J.G., Krabbenhoft D.P., Heinz G.H. and Scheuhammer A.M. (2003). Ecotoxicology of mercury. In: Hoffman DJ, Rattner BA, Burton GA, Cairns JS, ed., Handbook of ecotoxicology, Lewis Publ, Boca Raton, pp. 409-463. 
Wilhelm S.M. (2001). Mercury in petroleum and natural gas: estimation of emissions from production, processing, and combustion. In: EPA/600/R-01/066 (NTIS PB2001-109026), U.S. Environmental Protection Agency, Washington

Williamson B.J., Purvis O.W., Mikhailova I.N., Spiro B. and Udachin V. (2008). The lichen transplant methodology in the source apportionment of metal deposition around a copper smelter in the former mining town of Karabash, Russia. Environmental Monitoring and Assessment, 141 (1-3), pp. 227-236.

Xu M., Yan R., Zheng C., Qiao Y., Han J. and Sheng C. (2003). Status of trace element emission in a coal combustion process: a review. Fuel Processing Technology, 85, pp. 215- 237.

Yanchenko N.I., Slutskii S.L., Baranov A.N. and Verkhoturov V.V. (2015). Dynamics of fluoride atmospheric fallouts in the Baikal region. Russian Meteorology and Hydrology, 40 (11), pp. $766-771$.

Zhang Y., Xiu G., Wu X., Moore C.W., Wang J., Cai J., Zhang D., Shi C. and Zhang R. (2013). Characterization of mercury contents in snow and potential sources, Shanghai, China. Science of the Total Environment, 449, pp. 434-442.

Zharov Yu.N., Meitov E.S. and Sharova I.G .(1996). Valuable and toxic elements in traded coal of Russia. Handbook. Moscow: Nedra (in Russian) 